\title{
Control of postural alignment in patients with Parkinson's disease: analysis through postural software (SAPO)
}

Análise do alinhamento e controle postural do paciente com doença de Parkinson por meio do software de avaliação postural (SAPO)

Lúcia Martins Barbatto

Resumo da Tese de Doutorado apresentada à Faculdade de Medicina de São José do Rio Preto para obtenção do Título de Doutor no Curso de Pós-Graduação em Ciências da Saúde, Eixo Temático: Medicina e Ciências Correlatas.

Autora da Tese: Lúcia Martins Barbatto: Professora Assistente Dra. do Curso de Graduação em Fisioterapia da Faculdade de Ciências e Tecnologia da UNESP Campus de Presidente Prudente, Presidente Prudente SP, Brasil.

Orientador: Prof. Dr. Waldir Antonio Tognola. Professor Livre Docente no Curso de Pós-Graduação em Ciências da Saúde, Eixo temático: Medicina e Ciências Correlatas, São José do Rio Preto SP, Brasil.

Correspondence: Rua Antonio Lopes de Azevedo 146E / Vila Marcondes; 19031-100 Presidente Prudente SP - Brasil; E-mail: lubarbatto@fct.unesp.br

Received 22 May 2013; Accepted: 29 May 2013.

\begin{abstract}
This study assesses the alignment of posture and postural control in patients with Parkinson's disease (PD). Fifty individuals, aged 60-80 years, were viewed in the anterior, posterior, right lateral, and left positions by software for postural assessment (SAPO). The individuals were grouped according to the disease stage and the stage of medication (i.e. "on" or "off" levodopa). In the intermediate to advanced stages, there was a significant standard deviation in the horizontal alignment acromions, in the horizontal alignment of the anterior superior iliac spines, and in the angle between the acromia and the two anterior superior iliac spines. The side view of the left and right relationships was statistically significant for all variables. The "on" stage and the "off" stage groups showed no significant deviation. There was no statistically significant correlation between the center of gravity in the frontal and sagittal planes of the dominant hand and the side of symptom onset. In PD, individuals have increased cervical lordosis and thoracic kyphosis; an anteriorized head; reduced lumbar curvature; increased valgus, increased knee flexion angle; a decline in the support base; zero step; reduced postural stability; anteriorized center of gravity; and changes in the base of support.
\end{abstract}

Keywords: Parkinson, postural control, posture, SAPO. 